\title{
Research
}

\section{An Investigation of the Threshold Hypothesis Using ASIS and Creative Imagination Cards}

\section{Eşik Hipotezinin ASİS Puanları ve Yaratıcı Hayal Gücü Kartları İle İncelenmesi}

\author{
Gözde Yılmaz¹, M. Bahadır Ayas², \& Uğur Sak³
}

\begin{abstract}
In this study, it was aimed to examine the relationships between creative imagination and intelligence and to test the threshold hypothesis with younger students. The sample included 492 students aged 5-7 years. The Anadolu Sak Intelligence Scale was used to measure intelligence and Creative Imagination Cards were used to measure creativity. Firstly the relationship between intelligence and creative imagination scores were analyzed, and then the correlation values of the lower and upper groups were compared. To determine the threshold at other IQ levels, different from $120 \mathrm{IQ}$, segmented regression analysis were performed. A weak relationship was found between intelligence and creative imagination. The results showed that the threshold theory was not supported in younger children. Even, according to the segmented regression analysis, inverse threshold effect was observed between creative imagination scores and general intelligence scores around $120 \mathrm{IQ}$. This is interpreted as the fact that in contrast to the threshold hypothesis, intelligence level above the 120 IQ, provides an advantage in the creative imagination process for young age groups.

Key Words: threshold hypothesis, intelligence, creativity, imagination
\end{abstract}

\section{$\ddot{O ̈ z}$}

$\mathrm{Bu}$ çalışmanın amacı küçük yaş grubundaki öğrencilerde yaratıcı hayal gücü ve zekâ ilişkisinin incelenmesi, eşik hipotezinin test edilmesidir. Çalışmada 5-7 yaş arası 492 öğrenci yer almıştır. Zekânın ölçümünde Anadolu-Sak Zekâ Ölçeği; yaratıcılığın ölçümünde Yaratıcı Hayal Gücü Kartları kullanılmıştır. Analiz aşamasında zekâ ve yaratıcı hayal gücü puanları arasındaki ilişkilere bakılmış; hipotezde belirtilen 120 IQ düzeyine göre alt ve üst grupların korelasyon değerleri karşılaştırılmıştır. Başka düzeylerde eşik değerin varlığını test etmek için ise parçalı regresyon analizi yapılmıştır. Çalışmada zekâ ve yaratıcı hayal gücü arasında zayıf bir ilişki bulunmuş; küçük yaş gruplarında eşik hipotezi desteklenmemiştir. Hatta parçalı regresyon analizinde yaratıcılık endeksleri ile genel zekâ düzeyi arasında 120 IQ civarında ters bir eşik değer etkisi gözlenmiştir. Bu durum eşik hipotezinin aksine küçük yaş gruplarında sahip olunan zekâ bileşenlerinin, 120 IQ'nun üzerine çıkıldıkça yaratıcı hayal gücü sürecine avantaj sağladığı şeklinde yorumlanmıştır.

Anahtar Sözcükler: eşik hipotezi, zekâ, yaratıcılık, hayal gücü

\section{Summary}

Purpose and Significance: When studies dealing with the relationship between intelligence and creativity are examined in general, it is seen that researchers generally focus on the threshold hypothesis. When the threshold hypothesis studies are examined, it is observed that the research

\footnotetext{
" The paper is based on the first author's master thesis

${ }^{1}$ Corresponding Author, MS, Research assistant, Anadolu University, Faculty of Education, Eskisehir, Turkey, gozdeyilmaz845@anadolu.edu.tr, ORCID: 0000-0001-8074-4218

2 Assist. Prof., Center for Research and Practice for High ability Education (EPTS), Anadolu University, Faculty of Education, Eskisehir, Turkey, ORCID: 0000-0002-7560-9465

3 Prof., Director, Center for Research and Practice for High ability Education (EPTS), Anadolu University, Faculty of Education, Eskisehir, Turkey, ORCID: 0000-0001-6312-5239

(C) Talent; ISSN 2717-7122 http://talentjournal.net
} 
findings differ in the context of the participants' age group, the intelligence and creativity measurements used, and the analysis methods used. When these studies are examined in detail, there are no studies investigating the threshold hypothesis in young children with the dimension of imagination (Einstein, 1952; Gardner, 1983; Hu \& Adey, 2002; Glăveanu et al., 2017). However, imagination skill is considered as one of the main indicators of creativity, especially in the young age period (Gündoğan, 2019; Hoffmann \& Russ, 2012). In this regard, this study aimed to examine the threshold hypothesis in children in the younger age group (5-7 years old) with the creative imagination dimension.

Method: The study included 492 students aged 5-7, attending a private school and 1 public school, which were determined by easily accessible sampling method. Anadolu Sak Intelligence Scale (ASIS) developed by Sak et al. (2016) in determining the intelligence levels of students; Creative Imagination Cards (YHGK) developed by Yilmaz \& Ayas (2017) were used to determine creative imagination skills. Implementation data were collected by 11 practitioners who had received practitioner training on ASIS and YHGK. Implementations were made in environments prepared for individual practice in students' schools. First, the students were given YHGK for 6-7 minutes and ASIS for 20-45 minutes. In the analysis of the data, descriptive statistics were first made and the correlation coefficients between ASIS and YHGK were calculated for the whole group. Then, in order to test the threshold hypothesis, the participants were divided into lower $(\mathrm{IQ}<120)$ and upper $(\mathrm{IQ} \geq 120)$ groups according to their IQ level and the correlation coefficients between the YHGK and ASIS scores in both groups were examined. In order to determine whether the obtained correlation values have a significant difference from each other in the lower and upper groups, Fisher's formula for difference between standardized correlation coefficients was used (Can, 2017). Finally, in order to detect the presence of a certain threshold value other than 120 IQ, segmented regression analysis was performed using R Studio software using Segmented Package (Muggeo, 2008).

Results and Conclusion: As a result of the research, a weak relationship was found between intelligence and creative imagination, and the threshold hypothesis was not supported in young age groups. In fact, according to the segmented regression analysis, an inverse threshold effect of around 120 IQ was observed between the fluency, flexibility, originality and total creativity scores and the general intelligence level. Contrary to the threshold hypothesis, this situation has been interpreted as intelligence components in young age groups provide advantage in the creative imagination process as the IQ is exceeded.

\section{Giriş}

Hayal gücü yaratıcılığın en temel göstergelerinden birisi olarak özellikle küçük çocuklarda yaratıcılığın değerlendirilmesinde kullanılan temel bir beceridir. Literatüre bakıldığında hayal gücü becerisinin genellikle yaratıcı bir fikir veya ürün ortaya konulmadan önce zihinsel temsillerin üretilmesi, sürdürülmesi ve dönüştürülmesinde görev aldığ veya ürün üretiminde kullanıldığı görülmektedir (Kosslyn, 1980; Finke, 1996). Çocukların gelişimsel olarak deneyim eksiklikleri ve duygu kontrollerinin sınırlı olması, yetişkinlere göre daha zen- 
gin hayal kurmalarını sağlamaktadır (Vygotsky, 2004). Dolayısıyla erken çocukluk yıllarında, yaratıcılığın desteklenmesi veya değerlendirilmesinde hayal gücüne dayalı oyuna benzer görevlerin kullanılması önerilmektedir (Gündoğan, 2019; Hoffmann \& Russ, 2012).

Yaratıcılık ve hayal gücü üzerine çalışmalar incelendiğinde, bu iki kavramın teorik olarak sıklıkla ilişkilendirildiği görülmektedir. Teorik yaklaşımlarda hayal gücü, yaratıcı fikir üretimi sürecine ve üretilen fikirlerin kalitesine aracılık eden bir yapı olarak değerlendirilmektedir (Baddeley \& Andrade, 2000; Shaw \& de Mers, 1987). Ancak deneysel olarak bu ilişkinin ortaya koyulduğu çalışmaların görece daha az olduğu ve tutarlı araştırma bulgularına rastlanmadığı göze çarpmaktadır. Shaw \& Mers'e (1987) göre yaratıcılık ve hayal gücü arasındaki ilişkiye dair tutarsız araştırma bulgularının temel nedenleri ölçme araçları ve endeks farklılıkları ve zekânın bir değişken olarak araştırmaya dâhil edilme şeklidir. Öncelikle hayal gücü ve yaratıcılık ölçümlerinde kullanılan araçların (çoğul üretim, öz değerlendirme gibi) ve endekslerin farklı olması araştırma sonuçlarını etkilemektedir. Öte yandan zekâ-yaratıcılık ve zekâ-hayal gücü arasındaki ilişkilere dair yeterli ve tutarlı araştırma bulgusunun olmaması, zekânın etkili bir değişken olarak araştırmalara dâhil edilmemesine neden olmaktadır. Yaratıcılık ve zekâ arasındaki ilişkiye dair eşik hipotezi çalışmaları gibi çok sayıda teorik açıklama ve deneysel araştırma bulgusu olmasına rağmen (Cho, et al., 2010; Sligh et al., 2005), zekâ-hayal gücü ilişkisi üzerine sınırlı sayıda araştırmaya rastlanmaktadır. Eşik hipotezi çalışmaları incelendiğinde ise küçük yaş grupları ile yapılan çalışmaların çok az olduğu görülmektedir. Bu noktadan hareketle, bu araştırmada küçük yaş grubu çocuklarda yaratıcılık ve zekâ arasındaki ilişki, yaratıcılığın hayal gücü boyutu bağlamında incelenmiştir.

\section{Zekâ ve Yaratıcılık ile İlişkili Bir Beceri Olarak Yaratıcı Hayal Gücü Becerisi}

Hayal gücü, bir beceri olarak belli belirsiz anımsanan geçmiş deneyimlerin yeterli duyusal girdi olmaksızın zihinde yeniden birleştirildiği, dönüştürüldüğü ve şimdiki yaşantılarla ilişkilendirildiği zihinsel bir tasarlama süreci olarak tanımlanmaktadır (Vygotsky, 2004; Policastro \& Gardner, 1999; Singer, 1999). Süreç boyunca kurulan hayaller ise zihinde canlandırılan henüz tamamlanmamış, belli belirsiz resimler veya görüntülerdir (Thompson et al., 2011). Bu hayaller sayesinde Einstein, Proust, Beethoven gibi yaratıcı kişilerin normalde göremedikleri şeyleri zihinlerinde görme, buluş ve eserlerinde soyut düşüncelerini gerçeğe dönüştürmeden önce adeta zihinlerinde resmetme imkânı buldukları ifade edilmektedir (Daniels-McGhee \& Davis, 1994; Holton, 1972).

Kuramsal tanımlanan yaratıcılık ve hayal gücü arasındaki ilişki çeşitli araştırma bulguları ile de desteklenmektedir (Durndell \& Wetherick, 1976; Gonzalez et al., 1997; Shaw \& de Mers, 1987, Shaw, 1985). Kuramsal olarak ise Vygotsky (2004) bu ilişkiyi Yaratıcı Hayal Gücü Kuramı ile açıklamıştır. Kurama göre küçük yaş döneminde daha sık başvurdukları hayal gücü becerisinin, ilerleyen yaşlarda gelişmeye başlayan mantıksal düşünme becerisinin etkisi ile oluşan zihinsel kalıpların, orijinal fikir üretimini engelleyebildiğini ifade etmektedir. Çocukların küçük yaşlarda sahip oldukları oyuna benzer düşünme şekilleri -mış gibi yapma imkânı sağlayarak fikir üretmelerini desteklemektedir (Gündoğan, 2019; Lindqvist, 2003). Çünkü bu tip etkinlikler sayesinde çocuklar daha geniş bir duygu yelpazesini dile getirerek daha zengin hayal kurabilmektedirler. Bu bakımdan bi- 
limsel araştırma bulguları ve kuramsal açıklamalardan hareketle küçük yaş grubundaki çocukluklarda, yaratıcı potansiyelin ölçümünde hayal gücüne dayalı ekinliklerin daha işlevsel olabileceği düşünülebilir.

Yaratıcılık ve zekâ arasındaki ilişki (Cho et al., 2010; Getzels \& Jackson, 1960, 1962) düşünüldügünde, yaratıcılık ve hayal gücü arasındaki ilişkinin bireylerin bilişsel profilleriyle yakından ilişkili olabileceği görülmektedir. Sak (2004) yaratıcı çocukları akademik özel yetenekli çocuklardan ayıran en önemli özelliğin güçlü hayal gücü becerileri olduğunu belirterek, bu becerinin fikirleri nicelik ve nitelik bakımından zenginleştirdiğini ifade etmektedir. Tardif \& Sternberg (1988) ise yaratıcı bireyleri diğer bireylerden ayıran en temel özelliklerin başında ortalama üstü zekâ düzeylerinin, güçlü hayal gücü becerilerinin ve metaforik düşünme becerilerinin geldiğini belirtmektedir. Bu görüşlerin araştırma bulguları ile de desteklendiği görülmektedir. Örneğin Shaw \& de Mers (1987) ve Gonzalez et al., (1997) yaptıkları araştırmalarda yaratıcılık ve hayal gücü arasında hesaplanan korelasyon katsayılarının, yüksek IQ grubunda daha yüksek olduğunu rapor etmişlerdir.

Literatürde zekâ ve hayal gücü arasında doğrudan bir ilişki olduğuna dair çeşitli araştırma bulgularına rastlanmaktadır (Shaw, 1985; Shaw \& Belmore, 1982). Shaw \& de Mers'e (1987) göre hayal gücü becerisinin temelini bellek kapasitesi, hayal gücü canlılığı ve hayal gücü kontrolü oluşturmaktadır. Kişinin sahip olduğu bellek kapasitesi zihinde imgelerin üretilmesi, sürdürülmesi ve dönüştürülmesinde görev alırken (Kosslyn, 1980); hayal gücü canlılı̆̆1 daha fazla detay hatırlanmasını ve daha güçlü hayaller kurulmasını sağlamaktadır. Hayal gücü kontrolü ise üretilen çok sayıda hayalden hangilerinin seçilip değişiklik yapılabileceği konusunda oluşabilecek karışıklığı önlemektedir (Lane, 1977). Finke (1996) ise bu becerilerin yaratıcılık öncesi üretkenlik aşamasında eş güdümlü çalışarak, yaratıcılığın ileriki aşamalarında kullanılacak olan zihinsel temsillerin oluşturulmasında etkili olduğunu belirtmektedir. Bu bakımdan bellek kapasitesi ile hayal gücü arasında bir ilişkinin olması beklenebilir.

Yapılan çalışmalar hayal gücü ve zekâ arasındaki ilişkinin, bellek kapasitesi ile yakından ilişkili olabileceğini göstermektedir. Örneğin Baddeley \& Andrade (2000) 18-57 yaş arası bireylerle yürüttükleri çalışmalarında hayal gücü canlılığının işleyen bellekteki zihinsel temsil zenginliğine bağlı olduğunu, işleyen bellek olmaksızın katılımcıların bir uyaranı ondan hayal kurabilecek kadar uzun hatırlayamadıklarını, verilen eş zamanlı başka bir uyaranın asıl uyarana dayalı hayal gücü canlılığını azalttığını, uzun süreli belleğin işleyen bellek yerine geçmese de en az onun kadar hayal gücü canlılığını artırdığını tespit etmişlerdir. Benzer şekilde Hanggi (1988) de hayal gücü becerisi yüksek olan katılımcıların hem kısa süre içinde görselleri doğru hatırlama ve farklarını bulma hem de resim detaylarını doğru hatırlama görevlerinde anlamlı düzeyde daha başarılı performans sergilediklerini ortaya koymuştur. Çalışmada bu durum hayal gücü canlılığındaki farklılıkların sahip olunan kısa süreli ve uzun süreli bellek becerileriyle ilişkili olabileceği şeklinde yorumlanmıştır.

\section{Zekâ-Yaratıcılık İlişkisi}

Zekâ ve hayal gücü arasındaki ilişkinin zekâ-yaratıcılık ilişkisi ile yakından ilişkili olduğu düşünülebilir. Zekâ-yaratıcılık ilişkisinin açıklanmasında ise araştırmacıların sıklıkla eşik hipotezine odaklandığı görülmektedir. Eşik hipotezine göre üst düzey yaratıcılık için ortalamanın üzerinde 
bir zekâ düzeyi gerekse de bu yaratıcılık için yeterli bir koşul değildir (Guilford, 1967). Buna göre belirli bir eşik zekâ düzeyine kadar (genellikle 120 IQ) zekâ ve yaratıcılık arasında gözlenen pozitif ve anlamlı ilişki, eşik zekâ düzeyinin üzerinde kaybolmaktadır. Eşik hipotezini test etmek için yapılan çalışmalarda ise birbirleri ile çelişen araştırma bulguları rapor edilmektedir. Örneğin Getzels \& Jackson (1960; 1962), Cho et al., (2010) gibi isimler çalışmalarında eşik hipotezini destekleyen sonuçlara ulaşırken; benzer örneklemlerde eşik değerin rastlanmadığı (Preckel et al., 2006) veya ters bir eşik değerin rapor edildiği (Ferrando et al., 2016; Sligh et al., 2005; Şahin, 2004, 2015) çalışmalara da rastlanmaktadır. Preckel et al., (2006) çalışmalardan elde edilen sonuçların, çalışılan örneklem grubunun özellikleri, kullanılan ölçme araçları, ölçülen zekâ ve yaratıcılık bileşenleri, IQ kesme noktaları ve kullanılan analiz yöntemlerine göre farklılaştığı belirtmektedir.

Literatüre bakıldığında eşik hipotezi üzerine yapılan çalışmaların genellikle 4. sınıftan itibaren ortaokul, lise ve üniversite düzeyindeki öğrenciler ve yetişkinlerle yürütüldüğü görülmektedir. Küçük yaş gruplarında ise az sayıda çalışmaya rastlanmaktadır. Bu çalışmalardan Kim'in (2005) meta analiz çalışmasında eşik hipotezinin desteklenmediği; ilkokul öğrencileri için zeka ve yaratıcılık arasında hesaplanan düşük korelasyon katsayılarının, lise öğrencileri ve yetişkinlerde yükseldiği rapor edilmiştir. Çalışmada bu değişim yaş ile birlikte artan eğitimsel deneyimlerle açılanmıştır. Fuchs-Beauchamp, Karnes ve Johnson (1993) ve Şahin'in (2014) çalışmalarında ise küçük yaş gruplarında eşik hipotezini destekleyen araştırma bulgularına ulaşılmışırı. Bu çalışmalar yakından incelendiğinde yaratıcılığın ölçümünde yaratıcılık testlerinin ve çoğul düşünme görevlerinin kullanıldığı, eşik hipotezinin yalnızca genel IQ puanıyla ve tek bir kesme noktası kullanılarak test edildiği, örneklem grubunda zekâ testi ağırlıklı öğrenci seçimi yapan programlara devam öğrencilerin yer aldığı görülmektedir. Dolayısıyla küçük yaş gruplarında çalışmaların genel örneklemi daha çok yansıtan öğrencilerle, farklı ölçme araçlarına dayalı zekâ ve yaratıcılık bileşenleriyle ve farklı eşik değerlerini test edebilecek yeni analiz yöntemleriyle incelenerek zenginleştirilmesi gerektiği düşünülmektedir.

Eşik hipotezi araştırmalarında rapor edilen tutarsız bulguların bir diğer nedeni ölçülen zekâ ve yaratıcılık bileşenleri olmuştur. Son yıllarda ölçeklerde yaşanan gelişmelerle birlikte genel IQ'nun yanı sıra akıcı zekâ, kristalize zekâ, bellek kapasitesi gibi farklı bileşenler de işe koşulmaya başlanmıştır. Örneğin Cho et al., (2010) çalışmalarında akıcı zeka bileşeni için eşik hipotezine rastlamazken, kristalize zekâ için eşik hipotezini destekleyen bulgulara ulaşmışlardır. Karwowski ve Gralewski (2013) ise akıcı zekâ için eşik hipotezinin desteklendiğini rapor etmişlerdir. Buna karşın Sligh et al., (2005) ise akıcı zekâ ve genel zekâ için 120 IQ düzeyinde ters bir eşik değer etkisine ulaşırken kristalize zekâ için herhangi bir eşik değere rastlamamışlardır. Çalışmada bu durum yüksek IQ'ya sahip olan bireylerde akıcı zekânın soyut muhakeme ve esnek düşünme ile birlikte daha yüksek bir yaratıcılığa imkân vermesiyle açıklanmıştır. Eşik hipotezinin bellek bileşenlerinden etkilenip etkilenmediğini inceleyen Preckel et al., (2006) ise bellek, hız ve işlem kapasitesi bileşenlerinin sonuçlar üzerinde bir etkisinin olmadığını; ancak işleme kapasitesinin üstün zekâlı bireylerde zekâ-yaratıcılık ilişkisini artırdığını tespit etmişlerdir.

Genellikle çalışmalarda 120 IQ yaygın bir şekilde önceden test edilecek olası bir eşik değer olarak kabul edilmektedir. Ancak kullanılan IQ kesme noktaları ve analiz yöntemleri sonuçları etkileye- 
bilmektedir. Öncül araştırmalarda kullanılan zekâ puanları alt $(\mathrm{IQ}<120)$ ve üst $(\mathrm{IQ} \geq 120)$ grup şeklinde ikiye ayrılarak eşik hipotezi test edilirken (Guilford, 1962; Getzels \& Jackson, 1960, 1962; Torrance, 1962) bazı çalışmalarda IQ puanları daha dar aralıklara bölünerek korelasyon değerleri incelenmeye başlanmıştır (Cicirelli, 1965; Ripple \& May, 1962; Runco \& Albert,1986). Ancak belirlenen aralıkların üst gruplarda standart sapma ve ranjı düşürdügü için korelasyon değerlerini de düşürdüğünü savunan Sligh et al., (2005) bu sorunu çözmek üzere 120 IQ’nun altında ve üstünde benzer örneklem büyüklüğüne ulaşarak hipotezi test ettiklerinde hipotezin aksine üst grupta daha yüksek bir ilişkiye alt grupta ise zayıf bir ilişkiye ulaşmışlardır. Son yıllarda hipotezin IQ kesme noktaları yerine açıklayıcı değişkenin aldığı değere göre yordanan değişkendeki ani değişim noktasını (eşik IQ) saptayabilen parçalı regresyon analiziyle (Muggeo, 2008) incelenmeye başlandığı görülmektedir. Bu bağlamda Jauk, Benedek, Dunst \& Neubauer (2013) yaratıcılığın akıcılık boyutunda 85 IQ, orijinallik boyutunda $100 \mathrm{IQ}$, daha zorlu orijinallik görevlerinde ise 120 IQ düzeyinde eşik değer tespit ederken; Mourgues et al., (2016) parçalı regresyon analizi ile 108 IQ düzeyinde elde ettikleri ters eşik değeri kültürel ve eğitimsel farklılıklarla açıklamışlardır. Son olarak Shi et al., (2017) eşik hipotezinin genel zekâ ve yaratıcılık için 110 IQ, akıcılık ve esneklik için 109 IQ, orijinallik için ise 116 IQ düzeyinde desteklendiğini rapor etmişlerdir. Sonuç olarak eşik değerin kullanılan ölçme araçları, endeksler, analiz yöntemleri ve yaş gruplarına göre farklılaşması küçük yaş gruplarında da güncel çalışmalara ihtiyaç duyulduğunu göstermektedir.

Zekâ ve yaratıcılık arasındaki ilişkinin incelendiği çalışmalar genel olarak değerlendirildiğinde araştırmacıların eşik hipotezine odaklandığı görülmektedir. Eşik hipotezi çalışmaları incelendiğinde ise araştırma bulgularının katılımcıların yaş grubu, kullanılan zekâ ve yaratıcılık ölçümleri ve kullanılan analiz yöntemleri bağlamında farklılaştığı göze çarpmaktadır. Bu çalışmalar detaylı bir şekilde incelendiğinde ise eşik hipotezinin, yaratma sürecinde çok önemli bir yer tutan hayal gücü (Einstein, 1952; Gardner, 1983; Hu \& Adey, 2002; Glăveanu et al., 2017) boyutuyla küçük yaş grubu çocuklarında araştırıldığı çalışmalara rastlanmamaktadır. Bu bakımdan bu çalışmada eşik hipotezinin küçük yaş grubundaki (5-7 yaş) çocuklarda yaratıcı hayal gücü boyutu ile incelenmesi amaçlanmıştır. Bu amaç doğrultusunda öncelikle yaratıcı hayal gücü ve zekâ arasındaki ilişki incelenmiş, yaratıcı hayal gücü bağlamında 120 IQ için eşik hipotezi test edilmiş ve son olarak parçalı regresyon analizi ile olası eşik IQ değerleri araştırılmıştır.

\section{Yöntem}

\section{Çalışma Grubu}

Çalışmaya kolay ulaşılabilir örnekleme yolu ile belirlenen bir özel okul ve 1 devlet okuluna devam eden 5-7 yaş arası 492 öğrenci katılmıştır. Örneklem grubunun Anadolu Sak Zekâ Ölçeği (ASİS) puanlarına göre ortalama zekâ düzeyi 105,32 IQ (SS=12,50), en yüksek zekâ düzeyi 152 IQ, en düşük zekâ düzeyi 80 IQ'dur. Öğrencilerin yaş düzeylerine göre dağılımları Tablo 1'de yer almaktadır. 
Tablo 1. Yaş Düzeylerine Göre Çalışmaya Katılan Öğrenci Sayısı

\begin{tabular}{lc}
\hline Yaş & Toplam Katılımcı \\
\hline 5 Yaş & 29 \\
5,5 Yaş & 66 \\
6 Yaş & 379 \\
7 Yaş & 18 \\
\hline Toplam Katılımcı & 492 \\
\hline
\end{tabular}

\section{Veri Toplama Araçları}

Çalışmada öğrencilerin zekâ düzeylerinin belirlenmesinde Sak ve diğerleri (2016) tarafından geliştirilen Anadolu Sak Zekâ Ölçeği (ASİS); yaratıcı hayal gücü becerilerinin belirlenmesinde ise Yılmaz ve Ayas (2017) tarafından geliştirilen Yaratıcı Hayal Gücü Kartları (YHGK) kullanılmıştır.

Anadolu Sak Zekâ Ölçeği. 4-12 yaş arası çocukların zekâ düzeylerini belirlemek üzere Sak ve diğerleri, (2016) tarafından geliştirilen ASİS sözel ve görsel olmak üzere yedi alt testten oluşmaktadır. Kuramsal olarak Cattell-Horn-Carroll Zekâ Modeline, Baddeley'in bellek modeline ve Luria'nın nöropsikolojik işleme modeline dayanmaktadır. ASIS' in yapısında bulunan alt testlerin kuramsal olarak birleşimi ile Sözel Potansiyel Endeks (SPE), Görsel Potansiyel Endeks (GPE), Bellek Kapasitesi Endeksi (BKE) ve Genel Zekâ Endeksi (GIQ) hesaplanmaktadır. SPE, dil gelişimi, sözcük bilgisi, anlam bilgisi, alana özgü bilgi gibi kültür ile ilişkilendirilen daha çok kristalize zekâya dayalı becerileri ölçerken; GPE, ilişkileri, benzerlikleri, farklılıkları ayırt etme, sınıflama, genelleme, çıkarım yapma, hipotez kurma gibi daha çok akıcı zekâya dair becerileri ölçmektedir. BKE ise alg1, dikkat, ardıl ve eş zamanlı işleme gibi kısa süreli bellek ve işleyen bellek becerilerini ölçmektedir. Birçok zekâ ölçeğinin yapısında yer alan GIQ ise bireyin bütün zihinsel fonksiyonlarının içinde yer aldığı genel zekâ düzeyini ölçmektedir. ASIS'in tüm endeksler bazında yüksek bir iç tutarlılık ( $\alpha=.95-.99)$, test tekrar test ( $\alpha=.89-.95)$ ve puanlayıcılar arası güvenirlik ( $\alpha=.96-1.00)$ değerlerine sahip olması güvenilir bir zekâ ölçeği olduğunu göstermektedir.

Yaratıcı Hayal Gücü Kartları. YHGK, küçük yaş gruplarında yaratıcı hayal gücü becerisini ölçmek üzere Vygotsky'nin (2004) Yaratıcı Hayal Gücü Kuramı ve Guilford'un (1962) çoğul düşünme görevlerine dayalı olarak Yılmaz ve Ayas (2017) tarafından geliştirilmiştir. YHGK sırasıyla gösterilen 6 soyut şekilden oluşmaktadır (Ek-A).

YHGK çocuklara bireysel olarak uygulanarak öğrenci yanıtları YHGK Kayıt Formuna kaydedilmektedir. Yanıtlar puanlanmasında çoğul düşünme görevlerinin değerlendirilmesinde kullanılan akıcılık, esneklik, orijinallik ve bileşik yaratıcılık (CQ) puanları hesaplanmaktadır. YHGK puanlanmasında kullanılan endeksler ve formülleri aşağıdaki gibidir:

- Akıcılık: Kriterlere uygun cevap sayısıdır.

- Esneklik: Yanıtların sınıflandırıldığı kavramsal kategorilerin sayısıdır.

- Orijinallik: Herhangi bir yanıtın katılımcılar arasında rastlanma sıklığıdır. Orijinallik puanları (1-f/n) formülü kullanılarak hesaplanmaktadır. Formülde $f$ herhangi bir yanıtın üretilme sıklığını ifade ederken, $n$ katılımcı sayısını ifade etmektedir. 
- Bileşik yaratıcılık (Creativity Quotient-CQ): Akıcılık puanlarının orijinallik puanı üzerindeki etkisini azaltmak için Synder et al. (2004) tarafından geliştirilen, akıcılık ve esneklik puanlarının birlikte kullanıldığı $C Q=\log 2\{(1+u 1)(1+u 2) \ldots \ldots . .(1+u c)\}$ formülü ile hesaplanmaktadır. Bu formülde bulunan $u c$ değeri herhangi bir kategori için verilen uygun cevap sayısını ifade etmektedir.

YHGK'nın geçerlik çalışmasında 4 uzmanın görüşü alınarak içerik geçerliği sağlanmış, yapı geçerliği için korelasyon matrisi üzerinden maddelerin homojenliği incelenmiştir. Güvenirlik analizlerinde ise Cronbach Alpha iç tutarlık katsayıları ve maddeler arası korelasyon ve madde toplam korelasyonları hesaplanmıştır. Yapılan değerlendirmeler sonucunda YHGK'nın geçerlik ve güvenirlik bulgularının yeterli düzeyde olduğu görülmüştür (Yılmaz, 2018). Araştırma kapsamında 492 katılımcıdan elde edilen veriler ile iç tutarlılık analizleri yapılmış ve korelasyon matrisi incelenmiştir. Buna göre araştırmada kullanılan veriler üzerinden hesaplanan Cronbach Alpha iç tutarlılık katsayıları akıcılık, esneklik ve orijinallik puanları için sırasıyla.86, .81 ve .86 olarak bulunmuş, madde-toplam korelasyonlarının ise .42 ve .71 arasında değiştiği görülmüştür. Bu bulgular ış1ğında YHGK'nın güvenirliğinin yeterli düzeyde olduğuna karar verilmiştir (Akbulut, 2010; Büyüköztürk, 2010; Pallant, 2009). YHGK'nın yapı geçerliği için incelenen korelasyon matrisinde, maddeler arası korelasyon katsayılarının .30'un üzerinden olması maddelerin homojen dağıldığı şeklinde yorumlanmıştır (Akbulut, 2010; Pallant, 2009).

\section{Verilerin Toplanması ve Analizi}

Çalışmanın verileri toplanmadan önce gerekli etik kurul izinleri alınmış, ilgili okullarla iletişime geçilerek uygulamalar için gerekli katılımcı izinleri alınmıştır. Uygulama verileri ASİS ve YHGK konusunda uygulayıcı eğitimi almış 11 uygulayıcı tarafından toplanmıştır. Uygulamalar öğrencilerin okullarında bireysel uygulama için hazırlanmış ortamlarda yapılmıştır. Öğrencilere ilk olarak 6-7 dk süren YHGK ve 20-45 dk süren ASİS uygulaması yapılmıştır.

Verilerin analizinde ilk olarak betimsel istatistikler yapılmış ve tüm grup için ASIS ve YHGK arasındaki korelasyon katsayıları hesaplanmıştır. Ardından eşik hipotezini test etmek amacıyla katılımcılar IQ düzeyine göre alt $(\mathrm{IQ}<120)$ ve üst $(\mathrm{IQ} \geq 120)$ gruplara ayrılarak her iki grup içinde YHGK ve ASİS puanları arasındaki korelasyon katsayıları incelenmiştir. Ulaşılan korelasyon değerlerinin alt ve üst grupta birbirinden anlamlı bir farka sahip olup olmadığını belirlemek için Fisher'ın standartlaştırılmış korelasyon katsayıları arasındaki fark formülü kullanılmıştır (Can, 2017). Son olarak 120 IQ dışında belirli bir eşik değerin varlığını tespit etmek amacıyla R Studio yazılımı üzerinden Segmented Paket (Muggeo, 2008) kullanılarak parçalı regresyon analizi yapılmıştır.

\section{Bulgular ve Yorumlar}

\section{Betimsel Bulgular}

Çalışmada ilk olarak araştırmaya katılan 492 öğrencinin ASİS ve YHGK bazında alt test puan dağılımlarına ilişkin betimsel analizler yapılmış ve bulguları Tablo 2' de verilmiştir. Tablo 2'ye göre katılımcıların tüm endeksler için ortalama puanları normal zekâ aralığında (85-115 IQ) yer almaktadır. Endeks puanları için hesaplanan standart sapma değerlerinin ise norm örneklemi standart 
sapma değerine (15 IQ) yakın değerler aldığı görülmektedir. YHGK puanlarının maksimum ve minimum değerleri, ortalama ve standart sapma değerleri ile birlikte değerlendirildiğinde, YHGK uygulamasında tüm katılımcıların en az 2 yanıt üretebildiği görülmektedir. Bu bakımdan YHGK için görevlerin çok zor olmasından kaynaklanan taban etkisinin veya görevlerin çok açık uçlu olmasından kaynaklanan tavan etkisinin olmadığı düşünülebilir.

Tablo 2. 492 Öğrencinin Zekâ ve Yaratıcı Hayal Gücü Endeks Puanları

\begin{tabular}{clcccc}
\hline & & Min & Max & Ort. & SS \\
\hline \multirow{4}{*}{ ASİS } & GIQ & 80 & 152 & 105,32 & 12,50 \\
& SPE & 64 & 160 & 105,24 & 13,22 \\
& GPE & 64 & 160 & 108,40 & 13,40 \\
& BKE & 61 & 154 & 101,20 & 13,60 \\
\hline \multirow{4}{*}{ YHGK } & AKICILIK & 68 & 37 & 14,96 & 6,15 \\
& ESNEKLIK & 2 & 27 & 11,53 & 4,42 \\
& ORIjIINALLIK & 2 & 33,02 & 11,65 & 5,77 \\
& CQ & 0,82 & 30,80 & 12,82 & 5,25 \\
\hline
\end{tabular}

GIQ: genel zeka endeksi; SPE: Sözel potansiyel endeksi; GPE: Görsel potansiyel endeksi; BKE: Bellek kapasitesi endeksi

\section{Zekâ ve Yaratıcı Hayal Gücü Arasındaki İlişki}

Çalışmanın temel amaçlarından biri zekâ ve yaratıcı hayal gücü arasındaki ilişkinin belirlenmesidir. Bu doğrultuda ASİS'ten elde edilen zekâ puanları ve YHGK'dan elde edilen yaratıcılık puanları arasındaki ilişki Pearson Momentler korelasyon katsayıları hesaplanarak incelenmiştir. Tablo 1 'de ASİ ve YHGK endeksleri arasındaki korelasyon katsayıları ve determinasyon katsayıları $\left(\mathrm{r}^{2}\right)$ verilmiştir.

Tablo 3. ASIS ve YHGK Puanları Arasındaki Korelasyon ve Determinasyon Katsayıları

\begin{tabular}{|c|c|c|c|c|c|c|}
\hline $\mathrm{N}=492$ & AKICILIK & ESNEKLIK & ORİJİNALLİK & CQ & rortalama & $\mathbf{r}^{2}$ ortalama \\
\hline GIQ & $0,190^{* *}$ & $0,213^{* *}$ & $0,182^{* *}$ & $0,206^{* *}$ & 0,197 & 0,04 \\
\hline SPE & $0,107^{*}$ & $0,136^{* *}$ & $0,098^{*}$ & $0,115^{*}$ & 0,114 & 0,01 \\
\hline GPE & $0,111^{*}$ & $0,144^{* *}$ & $0,100^{*}$ & $0,124^{* *}$ & 0,119 & 0,01 \\
\hline BKE & $0,170^{* *}$ & $0,201^{* *}$ & $0,171^{* *}$ & $0,182^{* *}$ & 0,181 & 0,03 \\
\hline Ortalama & 0,144 & 0,177 & 0,137 & 0,157 & 0,154 & 0,02 \\
\hline
\end{tabular}

* $\mathrm{p}<.05{ }^{* *} \mathrm{p}<.01$

Tablo 3'te görüldüğü üzere ASİS zekâ endeksleri ve yaratıcı hayal gücü endeksleri arasında zayıf fakat anlamlı korelasyon katsayıları hesaplanmıştır. Elde edilen korelasyon katsayıları kullanılarak hesaplanan determinasyon katsayılarına bakıldığında ise zekâ endekslerinin yaratıcı hayal gücü endekslerini \%1 ile \% 4 arasında değişen düzeylerde açıkladığı görülmektedir. Bu durum yaratıcı hayal gücü potansiyelini zekânın dışında açıklayan daha farklı faktörlerin de olduğunu göstermektedir. Bununla birlikte GIQ ve BKE ile YHGK endeksleri arasında hesaplanan korelasyon katsayılarının SPE ve GPE için hesaplanan korelasyon katsayılarından nispeten daha yüksek olması bellek kapasitesinin zekâ-yaratıcllık ilişkisini etkileyebileceğini göstermektedir. 


\section{Zekâ ve Yaratıcı Hayal Gücü Arasındaki İlişki için Eşik Hipotezinin Test Edilmesi}

Çalışmanın bir diğer önemli amacı da zekâ ve yaratıcı hayal gücü için eşik hipotezinin var olup olmadığının incelenmesidir. Bu amaç doğrultusunda eşik zekâ değeri olarak 120 IQ belirlenmiş ve katılımcılar bu eşik değere göre iki gruba ayrılmıştır. Eşik değerin üzerinde 65 ve altında ise 427 katılımcı olduğu görülmüştür. Alt ve üst gruplardaki katılımcı sayılarının farklılığı, eşik değerin yapay bir istatistiksel olgu olarak ortaya çımasına neden olabileceğinden (Sligh et al., 2005), alt gruptaki 427 öğrenci arasından rastsal olarak 65 öğrenci seçilerek üst gruptaki kişi sayısına eşitlenmiştir. Gruplardaki katılımcı sayıları eşitlendikten sonra alt ve üst gruplar için korelasyon katsayıları ayrı ayrı hesaplanmış ve elde edilen korelasyon katsayıları Tablo 3'te verilmiştir.

Tablo 3. 120 IQ'nun Altında ve Üzerinde Yaratıcı Hayal Gücü ve Zekâ Endeksleri Arasında Hesaplanan Korelasyon Katsayıları

\begin{tabular}{|c|c|c|c|c|}
\hline & & $\begin{array}{l}\text { Alt Grup } \\
(\mathrm{IQ}<120)\end{array}$ & $\begin{array}{l}\text { Üst Grup } \\
(\mathrm{IQ} \geq 120)\end{array}$ & Fisher's \\
\hline & & ralt $(N=65)$ & rüst $(\mathrm{N}=65)$ & $\mathbf{z}$ \\
\hline & AKICILIK & 0.163 & $0.248^{*}$ & 0.49 \\
\hline & ESNEKLİK & $0.227^{*}$ & $0.297^{*}$ & 0.42 \\
\hline 4 & CQ & $0.189^{*}$ & $0.276^{*}$ & 0.51 \\
\hline & ORİJINALLIKK & 0.153 & $0.212^{*}$ & 0.34 \\
\hline Ort & na Korelasyon & 0.183 & 0.258 & 0.44 \\
\hline & Ortalama IQ & 104 & 126,24 & \\
\hline & Standart Sapma & 10,35 & 8,43 & \\
\hline & AKICILIK & 0.009 & 0.128 & 0.67 \\
\hline & ESNEKLIKK & 0.030 & 0.181 & 0.85 \\
\hline जे & CQ & 0.017 & 0.156 & 0.78 \\
\hline & ORİJiNALLIK & -0.006 & 0.084 & 0.50 \\
\hline Ort & na Korelasyon & 0.013 & 0.137 & 0.70 \\
\hline & Ortalama IQ & 106 & 120,87 & \\
\hline & Standart Sapma & 10,66 & 10,78 & \\
\hline & AKICILIK & 0.095 & 0.158 & 0.36 \\
\hline & ESNEKLİK & 0.110 & 0.229 & 0.68 \\
\hline$\hat{0}$ & $\mathrm{CQ}$ & 0.101 & 0.187 & 0.49 \\
\hline & ORİJiNALLİK & 0.099 & 0.169 & 0.40 \\
\hline Ort & na Korelasyon & 0.101 & 0.185 & 0.48 \\
\hline & Ortalama IQ & 105,46 & 124,04 & \\
\hline & Standart Sapma & 12,41 & 12,30 & \\
\hline & AKICILIK & 0.201 & $0.243^{*}$ & 0.25 \\
\hline & ESNEKLİK & $0.205^{*}$ & $0.266^{*}$ & 0.36 \\
\hline$\frac{\vec{v}}{\infty}$ & CQ & $0.221^{*}$ & $0.256^{*}$ & 0.31 \\
\hline & ORİJINALLIKK & 0.190 & $0.243^{*}$ & 0.31 \\
\hline Ort & na Korelasyon & 0.214 & 0.252 & 0.22 \\
\hline & Ortalama IQ & 99,26 & 120,09 & \\
\hline & Standart Sapma & 11,53 & 10,36 & \\
\hline
\end{tabular}

* $\mathrm{p}<.05$ 
Tablo 3 genel olarak incelendiğinde eşik zekâ değeri olarak belirlenen 120IQ'nun hem altında ve hem de üzerinde GIQ ve BKE için zeka ve yaratıcı hayal gücü endeksleri arasında anlamlı korelasyon katsayıları bulunurken, SPE ve GPE için her iki grup için de hesaplanan korelasyon katsayılarının anlamlı olmadığı görülmüştür. Ayrıca tüm endeksler için üst grup için hesaplanan korelasyon katsayılarının alt grup için hesaplanan değerlerden nispeten daha yüksek olduğu ancak aradaki farkların istatistiksel olarak anlamlı olmadığı görülmektedir. Bu durum zekâ ve yaratıcı hayal gücü arasında ters bir eşik değeri işaret etse de bu bulgu istatistiksel olarak anlamlı değildir. Öte yandan BKE için de üst gruptaki korelasyon değerlerinin alt gruptan daha yüksek olmasına rağmen z değerlerinin anlamlı olmaması 120 IQ'nun ters bir eşik değer olarak yorumlanmasını güçleştirmektedir. Ancak SPE ve GPE'den farklı olarak BKE için hem alt grup hem de üst grupta bulunan korelasyon değerlerinin anlamlı olması 120 IQ düzeyinde ters bir eşik değer etkisi olmasa bile BKE düzeyi arttıkça zekâ-yaratıcılık ilişkisinin de zayıf bir artış gösterebileceğine işaret etmektedir.

\section{Parçalı Regresyon Analizine göre Alt ve Üst Gruplardaki Korelasyon Değerleri}

Çalışmada zekâ ve yaratıcı hayal gücü arasında 120 IQ dışında başka bir eşik değer için eşik hipotezinin olup olmadığını incelemek amacıyla parçalı regresyon analizi yapılmıştır. Belirli bir başlangıç parametresi (PSI) ile çalışan parçalı regresyon analizinde, aynı zamanda eşik hipotezinde yaygın olarak kabul edilen değer de test edilmek istendiğinden PSİ değeri 120 IQ şeklinde girilerek zeka ve yaratıcı hayal gücü endeksleri arasındaki korelasyon katsayıları incelenmiştir. PSİ değeri 120 IQ olarak belirlendiğinden eşik değerin altındaki ve üstündeki katılımcı sayıları eşitlenerek analizler 130 katılımcının verileri üzerinden yürütülmüştür. Analiz sonucunda elde edilen eşik IQ değerleri Tablo 4'te ve değerlere göre regresyon doğrularındaki kırılmalar Şekil 1'de verilmiştir.

Tablo 4. PSİ=120 IQ için zekâ ve yaratıcı hayal gücü endeksleri arasında bulunan eşik değerler ve gruplar arası korelasyon dağılımı

\begin{tabular}{|c|c|c|c|c|c|c|c|}
\hline & $\begin{array}{l}\text { PSİ=120 IQ } \\
n=130\end{array}$ & $\begin{array}{l}\text { EŞİK } \\
\text { DEĞER }\end{array}$ & $\begin{array}{l}\text { Alt Grup } \\
\text { ralt }\end{array}$ & & $\begin{array}{l}\text { Üst Grup } \\
\text { rüst }\end{array}$ & & $\begin{array}{l}\text { Fisher } \\
z\end{array}$ \\
\hline \multirow{4}{*}{ 의 } & AKICILIK & 122 & $0.161^{*}$ & $(\mathrm{~N}=76)$ & $0.237^{*}$ & $(\mathrm{~N}=54)$ & 0.43 \\
\hline & ESNEKLİK & 121 & $0.213^{*}$ & $(\mathrm{~N}=72)$ & $0.285^{*}$ & $(\mathrm{~N}=58)$ & 0.42 \\
\hline & CQ & 121 & $0.174^{*}$ & $(\mathrm{~N}=72)$ & $0.260^{*}$ & $(\mathrm{~N}=58)$ & 0.50 \\
\hline & ORİJINALLIKK & 113 & 0.081 & $(\mathrm{~N}=49)$ & 0.208 & $(\mathrm{~N}=81)$ & 0.70 \\
\hline
\end{tabular}

* $\mathrm{p}<.05$

Parçalı regresyon analizi bulgularına göre GIQ ile YHGK akıcılık, esneklik ve bileşik yaratıcılık endeksleri için olası eşik değerler sırasıyla 121 IQ, 122 IQ ve 121 IQ olarak bulunurken orjinallik endeksi için olası eşik değer 113 IQ olarak bulunmuştur. Her ne kadar regresyon doğruları bulunan eşik değerlerde kırılma gösterse de, bu eşik değerlere göre katılımcılar gruplandığında alt ve üst grup için hesaplanan korelasyon katsayılarının anlamlı olmadığı görülmektedir. Parçalı regresyon analizinde elde edilen eşik değerlerde zekâ endeksleri için eşik hipotezinin olup olmadığını incelemek amacıyla eşik değerlerin alt ve üstündeki gruplar için korelasyon katsayıları hesaplanmış ve bulgular Tablo 5'te verilmiştir. 

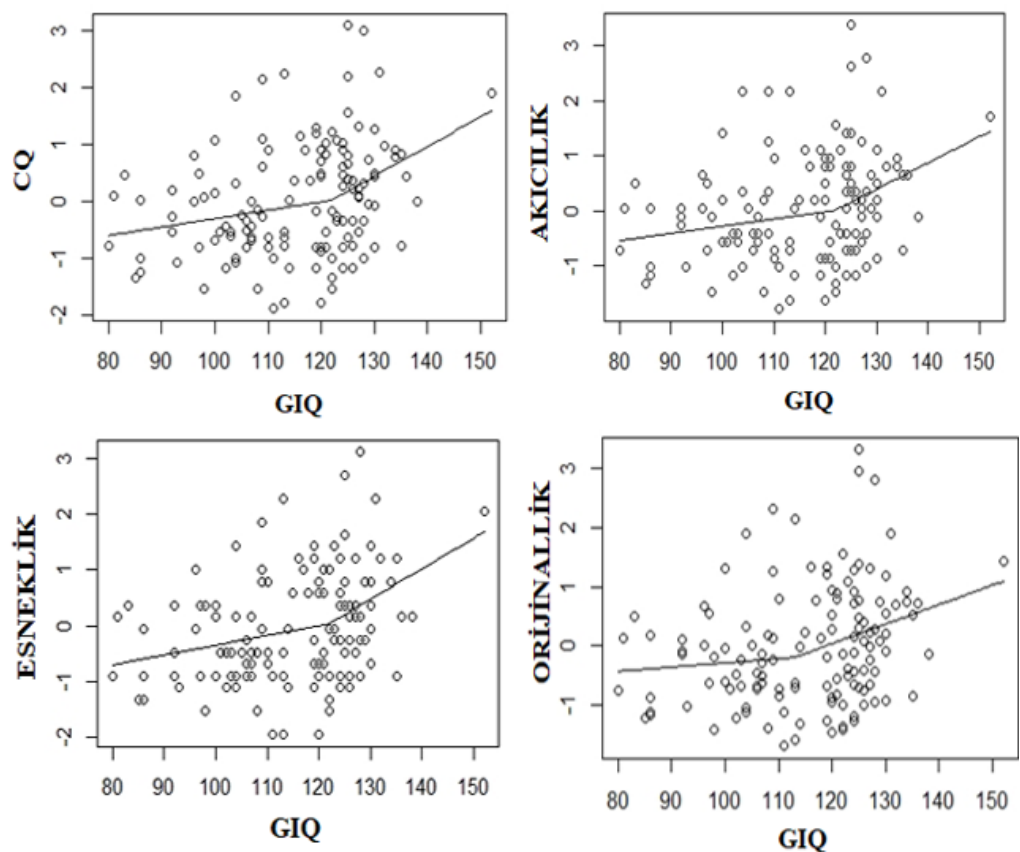

Şekil 1. Zekâ ve Yaratıı Hayal Gücü Endeksleri Arasında İlişki İçin Parçalı Regresyon Analizi Bulguları

Tablo 5. GIQ için Tespit Edilen Eşik Değerlere Göre Diğer Zekâ Endekslerinin Yaratıcı Hayal Gücü Endeksleri ile Alt ve Üst Gruplardaki Korelasyon Değerleri

\begin{tabular}{|c|c|c|c|c|c|}
\hline $\begin{array}{l}\text { Eşik Değer } \\
\text { (GIQ) }\end{array}$ & $\begin{array}{l}\text { Yaraticilik } \\
\text { Endeks }\end{array}$ & Grup & $\begin{array}{l}\text { SPE } \\
\mathrm{r}\end{array}$ & $\begin{array}{l}\text { GPE } \\
r\end{array}$ & $\begin{array}{l}\text { BKE } \\
\mathrm{r}\end{array}$ \\
\hline \multirow{3}{*}{122} & \multirow{3}{*}{ AKICILIK } & Alt $(\mathrm{N}=76)$ & 0.053 & 0.059 & 0.187 \\
\hline & & Üst $\quad(N=54)$ & 0.097 & 0.103 & $0.223^{*}$ \\
\hline & & $\mathrm{z}$ & .24 & .24 & .21 \\
\hline \multirow{3}{*}{121} & \multirow{3}{*}{ ESNEKLİK } & Alt $\quad(\mathrm{N}=72)$ & 0.046 & 0.074 & $0.234^{*}$ \\
\hline & & Üst $\quad(N=58)$ & 0.166 & 0.170 & $0.262^{*}$ \\
\hline & & $\mathrm{z}$ & .67 & .54 & .17 \\
\hline \multirow{3}{*}{121} & \multirow{3}{*}{ CQ } & Alt $\quad(\mathrm{N}=72)$ & 0.030 & 0.065 & $0.210^{*}$ \\
\hline & & Üst $\quad(N=58)$ & 0.137 & 0.129 & $0.246^{*}$ \\
\hline & & $\mathrm{z}$ & .39 & .36 & .21 \\
\hline \multirow{3}{*}{113} & \multirow{3}{*}{ ORİİNALLİK } & Alt $\quad(\mathrm{N}=49)$ & -0.112 & 0.021 & 0.183 \\
\hline & & Üst $\quad(N=81)$ & 0.084 & 0.109 & $0.216^{*}$ \\
\hline & & z & 1.06 & .48 & .18 \\
\hline
\end{tabular}

* $\mathrm{p}<.05$

Tablo 5'te görüldüğü üzere zeka ve yaratıcı hayal gücü endeksleri arasında düşük korelasyon katsayıları hesaplanmıştır. SPE ve GPE ile YHGK endeksleri arasında hesaplanan korelasyon katsayılarının hem üst grup hem de alt grup için oldukça düşük ve anlamlı olmadığı görülmektedir. BKE ile YHGK endekslerinden akıcılık ve orijinallik arasında hesaplanan korelasyon katsayılarının alt grup için anlamlı değilken üst grup için anlamlı olduğu, esneklik ve CQ için hesaplanan korelasyon katsayılarının ise hem üst grup hem de alt grup için anlamlı olduğu görülmektedir. Her ne kadar tüm endeksler arasında alt ve üst gruplar için hesaplanan korelasyon katsayılar arasındaki farklar istatistiksel olarak anlamlı olmasa da, üst gruplar için hesaplanan katsayıların daha yüksek olması ters bir eşiğe işaret etmektedir. 


\section{Sonuç, Tartışma ve Öneriler}

Araştırmada 4-7 yaş grubundaki çocuklarda zekâ ve yaratıcılık arasındaki ilişki yaratıcılığın hayal gücü boyutu kullanılarak incelenmiştir. Bunun için öncelikle yaratıcı hayal gücü ile zekâ arasındaki ilişkiye bakılmış, daha sonra ise bu ilişki yaratıcılığın eşik hipotezi bağlamında detaylı olarak incelenmiştir. Yapılan analizler sonucunda öncelikle zeka ve yaratıcı hayal gücü endeksleri arasında düşük fakat anlamlı korelasyon katsayıları bulunmuştur (.10-.21; p<.05). Zekâ ve yaratıcı hayal gücü arasındaki ilişkiye dair eşik hipotezi analizlerinde 120IQ puanının üzerindeki grupta korelasyon katsayılarının daha yüksek olduğu bulunmuştur. Devamında yapılan parçalı regresyon analizi bulgularına göre ise akıcılık, esneklik, CQ ve orijinallik için sırasıyla $121 \mathrm{IQ}, 122 \mathrm{IQ}, 121 \mathrm{IQ}$ ve 113 IQ eşik değerlerine ulaşılmış ve eşik değerin üstündeki grup için korelasyon katsayılarının görece daha yüksek olduğu görülmüştür.

Zekâ ve yaratıcı hayal gücü arasında bulunan zayıf korelasyon katsayıları (GIQ için rort=.20, SPE için rort=.11, GPE için rort=.12, BKE için rort=.18) alan yazında zeka ve yaratıcılık arasındaki ilişkinin incelendiği birçok araştırmanın (Ferrando et al., 2016; Fuchs et al., 1993; Kim, 2005; Preckel et al., 2006; Yamamoto, 1964) bulguları ile benzerlik göstermektedir. Preckel et al.'a (2006) göre çalışmalarda kullanılan zekâ ve yaratıcılık testlerinin birbirinden farklı becerileri ölçüyor olması, bireylerin zekâ ve yaratıcılık testlerinin eğitimlerinde aşina oldukları diğer testlerden farklı olması, stres, anksiyete gibi birtakım kişilik özelliklerinin ölçüm sürecine dâhil olması gibi faktörler zekâ-yaratıcılık ilişkisinin düşük çıkmasında etkili olabilmektedir. Örneğin zekâ ve yaratıcılığın ölçüm boyutunda birbirinden tamamen ayrıldığını ifade eden Sternberg'e (2004) göre doğru bir şekilde ölçüldüğünde zekânın tekil düşünme testleri ile yaratıcılığın ise çoğul düşünme testleri ile değerlendirilmesi zekâ-yaratıcılık ilişkisini düşürebilecek olası faktörlerden biridir. Çünkü açık uçlu soru veya problemlere dayanan çoğul düşünme testleri bireylerden çok sayıda fikir üretimi beklerken; kapalı uçlu sorulara dayanan tekil düşünme testleri tek veya az sayıda doğru yanıt üretilmesini bekleyen farklı bilişsel süreçlere dayanmaktadır (Guilford, 1967).

Zekâ ve yaratıcı hayal gücü ilişkisi genel olarak düşük çıkmakla birlikte çalışmada içinde bellek kapasitesine dair bileşenler taşıyan BKE ve GIQ endeksleri yaratıcı hayal gücü ile görece daha yüksek ilişkiler kurmuşlardır (GIQ için rort=.20, BKE için rort=.18, SPE için rort=.10, GPE için rort=.12). Bu bulgular Shaw ve de Mers (1987), Kosslyn, (1980), Lane (1977) ve Finke'nin (1996) görüşleri ile uyumlu görülmektedir. Yapılan bazı araştırmalarda da belleğin hayal gücü sürecinde zihinde imgelerin üretilmesi, sürdürülmesi ve dönüştürülmesinde görev aldığı, hayal gücü canlılığının işleyen bellekte üretilen zihinsel temsil zenginliğine bağlı olduğu, kısa süreli bellek, uzun süreli bellek ve işleyen bellek bozulduğunda uyaranın hayal kurulabilecek kadar uzun hatırlanamadığı veya dönüştürülemediği dolayısıyla hayal gücü canlılığının azaldığı tespit edilmiştir (Baddeley \& Andrade, 2000; Shaw \& de Mers, 1987). Öte yandan doğrudan hayal gücüne dayalı olmasa da yaratıcılık düzeyinin bellek kapasitesine dair beceriler ile ilişkisini ortaya koyan çalışmalarda da ilişkisel ve kontrollü dikkat, uzun süreli ve geri çă̆ırıcı bellek (glr), zihinsel işlem hızı (gs) gibi birtakım bellek becerilerinin yaratıcı süreçte akıcı zekâ (gf) ile birlikte bilginin hafızadan hızlı bir şekilde çă̆ırılmasını, bu sırada ipuçlarının sürdürülmesini ve akıcı düşünme sırasında gereksiz bilginin temiz-

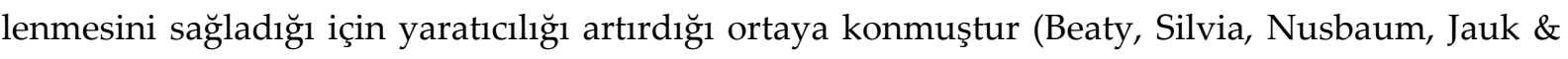
Benedek, 2014; Kaufman, Kaufman \& Lichtenberger, 2011; Nusbaum \& Silvia, 2011). Süreye dayall, 
hız gerektiren yaratıcılık görevlerinin kişide anksiyete ve stres düzeyini artırarak performans düzeyini olumsuz etkilediğini belirten Preckel et al.'a (2006) göre işleyen bellek ve mental hız becerilerini daha verimli kullanabilen bireyler bu süreci daha iyi yöneterek yaratıcılık görevlerinde daha başarılı olabilmektedir. Öte yandan akıcılık ve esnekliğin geniş bir bilgi arayışı ve çok sayıda yeni olasılık üretimi gerektirdiği belirten araştırmacılar çalışmalarında geri çağırma ve işlem hızının bu süreçte aktif rol oynayarak bireye avantaj sağlayabileceğini rapor etmişlerdir. Çalışmalarda elde edilen bu sonuçlar ulaşılan bulgular ile birlikte değerlendirildiğinde sahip olunan bellek kapasitesi bileşenlerinin çocuklarda hayal gücü sürecinin daha iyi yönetilmesini sağlayarak zekâ-yaratıcı hayal gücü ilişkisini de artırmış olabileceği düşünülmektedir. Öte yandan hayal gücü becerisinin yaratıcılık öncesi üretkenlik sürecinde görev aldığı düşünüldüğünde (Finke, 1996) zekâ-yaratıcılık ilişkisinin zekâ-yaratıcı hayal gücü arasında bulunan ilişkiye benzer olması bellek kapasitesi bileşenlerinin hayal gücü bileşenleri ile kurmuş olduğu ilişkilerden kaynaklanıyor olabilir.

Çalışmada ele alınan en önemli konulardan bir diğeri 120 IQ düzeyinde eşik hipotezinin desteklenip desteklenmediği olmuştur. Bu noktada yapılan analizler genel zekâ düzeyi ve yaratıcı hayal gücü becerisi arasında eşik hipotezinin desteklenmediğini; aksine 120 IQ düzeyinde gruplar arası korelasyon farkı anlamlı olmamakla birlikte ters bir eşik değer etkisinin ortaya çıktığını göstermektedir. Nitekim parçalı regresyon analiziyle de bulunan değerlerin orijinallik endeksi hariç 120 IQ civarında olması bu durumu desteklemektedir (CQ için 121 IQ, akıcılık için 122 IQ, esneklik için 121 IQ ve orijinallik için 113 IQ). Elde edilen sonuçlar eşik hipotezi üzerine yürütülen çalışmalardan katılımcı grubunun yaşı, kullanılan araçlar, ölçülen zekâ ve yaratıcılık bileşenleri, kullanılan analiz yöntemleri bakımından farklılık göstermektedir. Örneğin yapılan çalışmaların birçoğunda üst yaş grubu bireyler yer almaktadır (Cho et al., 2010; Getzels \& Jackson, 1963; Jauk et al., 2013; Karwowski \& Gralewski, 2013; Torrance, 1963). Ancak bazı araştırmacılara göre yaş düzeyi ve buna bağlı olarak artan eğitimsel deneyimler, öğrencilerden beklenen uyumsal davranışlar, akran baskısı, okul kuralları gibi kültürel ve çevresel faktörler zekâ-yaratıcılık ilişkisinin düşmesine neden olabilmektedir (Davis, 1999; Runco, 1999; Torrance, 1967; 1968). Bu noktada çalışmada yer alan örneklem grubunun okul öncesi, anasınıfı ve 1. sınıf düzeyindeki çocuklardan oluştuğu düşünüldüğünde henüz bahsedilen eğitim sürecinin beraberinde getirdiği bu durumlardan ve birtakım zihinsel kalıplardan kısmen daha az etkilendiği söylenebilir. Ayrıca üst gruptaki çocukların sahip oldukları daha gelişmiş bellek kapasiteleri zengin bir zihinsel temsil olanağı ile birlikte uyaranlara dayalı daha hızlı ve kolay dönüşümler yapabilmelerini sağlayarak (Baddeley \& Andrade, 2000) daha kısa sürede gerçeklik üstü bağlantılar kurmalarına olanak tanımış olabilir. Dolayısıyla bu çocuklar için normalin üstünde zekâ veya üstün zekâ potansiyeli yaratıcı hayal gücü sürecinde esnek düşünmeyi ve hayal kurmayı sınırlayan bir faktörden ziyade avantaj sağlayan bir faktöre dönüşüyor olabilir. Ancak yine de küçük yaş gruplarıyla yürütülen bazı çalışmalarda eşik hipotezini destekleyen yönde sonuçlara da ulaşılmıştır. Örneğin Fuchs-Beauchamp et al., (1993) okul öncesi çocuklarla yaptıkları çalışmalarında 120 IQ'nun altındaki öğrencilerde zayıf fakat anlamlı bir ilişki tespit ederken üst grupta bu ilişkinin kaybolduğunu belirlemişlerdir. Şahin (2014) ise normal ve orta düzeyde üstün zekâlı her iki öğrenci grubunda da zayıf fakat anlamlı bir ilişki elde etse de (sırasıyla r=.24, r=.21) yüksek düzeyde üstün zekâlı öğrenciler için ilişki tespit edilemediğinden sonuçların eşik hipotezini destekler yönde olduğunu savunmuştur. Ancak her iki çalışmada da üst 
gruplardaki öğrenciler zekâ testi ağırlıklı seçim yapan programlara devam eden öğrenciler oldukları için genel örneklemin yaratıcılık dağılımını yansıtmaması bir sınırlılık olarak görülmektedir (Fuchs-Beauchamp et al., 1993). Örneğin 130 IQ ve üzerinde puan alan öğrencilerin programlara dahil edilmesi, zeka puanlarının varyansının düşmesine dolayısı ile korelasyon katsayılarının da düşük olmasına neden olacaktır. Öte yandan her iki çalışmada da üst gruptaki öğrenci sayısının alt gruptan daha az olması standart sapma ve ranjı sınırlandırarak korelasyon değerlerinin düşmesine (Sligh et al., 2005; Pallant, 2017), alt grupta ise kişi sayısının fazla olması kişi sayısına bağlı olarak anlamlı ilişkiler elde edilmesine neden olmuş olabilir (Akbulut, 2010).

Araştırma bulgularının güncel eşik hipotezi araştırmalarının sonuçları ile benzerlik görülmektedir (Ferrando et al., 2016; Mourgues et al., 2016; Sligh, 2003; Sligh et al., 2005). Öyle ki bu çalışmada olduğu gibi küçük yaş gruplarında 115 IQ civarında ters bir eşik değer elde eden Ferrando et al., (2016) normalin üstünde zekâ potansiyelini yaratıcılık görevlerinin öğrenilmesini kolaylaştıran ve süreç sonunda daha yüksek bir performans ortaya konulmasını sağlayan bir faktör olarak değerlendirmektedir. Sligh et al., (2005) ise üst gruplarda (IQ $\geq 120)$ elde ettikleri daha yüksek korelasyon değerlerini, genel zekâ düzeyi yüksek olan bireylerde akıcı zekânın daha aktif çalışması sonucu yaratıcılığı artırması ile iliş̧kilendirmektedir. 108 IQ düzeyinde ters bir eşik değer elde eden Mourgues et al., (2016) ise çalışmalarında yer alan görev türlerine gerektirdiği bilişsel beceriye vurgu yaparak bu becerinin üst gruplarda daha yüksek olması nedeniyle zekâ-yaratıcılık ilişkisinin yükselmiş olabileceğini belirtmektedir. Yapılan çalışmalar kullanılan ölçekler detaylı incelendiğinde, yaratıcılık bileşenlerinin genel olarak içinde geometrik veya soyut şekillerin zihinde döndürülmesine dayalı zekâ testleriyle veya alt testlerle daha yakından ilişkili olduğu görülmektedir. Örneğin Ferrando et al.'ın (2016) çalışmasında kullanılan Cattell Kültürden Arındırılmış Zekâ Ölçeği ile zihinde döndürülen soyut geometrik şekillere dayalı görevlerle genel IQ puanı ölçülürken; Sligh et al., (2005)'nin çalışmalarında benzer görevlerle ölçülen akıcı zekâ bileşeni ile yaratıcılık arasında ters bir eşik değer etkisi bulunmuştur. Mourgues et al.'ın, (2016) çalışmasında ise yaratıcılık en çok zihinsel esneklik puanlarıyla ilişki kurmuştur. Bu noktada yapılan çalışmada ASİS'in yapısında bulunan bellek bileşenlerine dayalı görsel alt testlerin hayal gücü sürecinin gerektirdiği zihinde imgenin üretilmesi, sürdürülmesi, dönüştürülmesi, ilgili detayların hatırlanması ve değiştirilmesi gibi süreçlerle ilişki kurarak üst gruplarda zekâ ve yaratıcı hayal gücü arasındaki anlamlı ilişkilerin bulunmasına neden olmuş olabilir. Öte yandan diğer çalışmalarda kullanılan çoğul düşünme testlerinden farklı olarak bu çalışmada hayal gücü becerisinin tek bir göreve dayanıyor olması da öğrencilerde göreve olan alışkanlığı artırarak zihinsel becerilerini hayal gücü sürecinde daha etkili kullanmalarına olanak sağlamış olabilir. Dolayısıyla elde edilen bulgular genel olarak değerlendirildiğinde normalin üstünde zekâ potansiyeli farklı zekâ bileşenlerinin etkileşimine imkân vererek yaratıcı hayal gücü ile zekâ ilişkisinin yükselmesinde rol oynamış olabilir. Nitekim Tardif \& Sternberg (1988)'in de ifade ettiği gibi yaratıcılığın en azından standartlara göre belirgin düzeyde daha yüksek bir zekâ potansiyeli gerektirdiği düşünüldüğünde elde edilen sonuçlar bu görüş ile tutarlilık göstermektedir.

Çalışmadan elde edilen bulgular genel olarak değerlendirildiğinde zekâ ve yaratıcı hayal gücü arasında zayıf bir ilişkinin olduğu, eşik hipotezinin desteklenmediği, genel zekâ düzeyi için 120 IQ 
civarında ters bir eşik değer etkisinin elde edildiği ve diğer zekâ endekslerinde de anlamlı olmamakla birlikte üst gruptaki korelasyon değerlerinin alt gruptan nispeten daha yüksek olduğu görülmüştür. Bulguların korelasyon analizleri üzerinden elde edilmesi sonuçların yorumlanmasını zorlaştırsa da, erken çocukluk yıllarında hayal gücünün zeka gelişimi üzerinde etkilerinin olabileceği söylenebilir.

\section{Kaynakça}

Baddeley, A. D., \& Andrade, J. (2000). Working memory and the vividness of imagery. Journal of Experimental Psychology: General, 129(1), 126-145. https://doi.org/10.1037/00963445.129.1.126

Beaty, R. E., Silvia, P. J., Nusbaum, E. C., Jauk, E., \& Benedek, M. (2014). The roles of associative and executive processes in creative cognition. Memory $\mathcal{E}$ cognition, 42(7), 1186-1197. https://doi.org/10.3758/s13421-014-0428-8

Cho, S. H., Nijenhuis, J. T., Van Vianen, A. E., Kim, H. B., \& Lee, K. H. (2010). The relationship between diverse components of intelligence and creativity. The Journal of Creative Behavior, 44(2), 125-137. https://doi.org/10.1002/j.2162-6057.2010.tb01329.x

Cicirelli, V. G. (1965). Form of the relationship between creativity, IQ, and academic achievement. Journal of Educational Psychology, 56(6), 303-308. https://doi.org/10.1037/h0022792

Daniels-McGhee, S., \& Davis, G. A. (1994). The imagery-creativity connection. The Journal of Creative Behavior, 28(3), 151-176. https://doi.org/10.1002/j.2162-6057.1994.tb01189.x

Durndell, A. J., \& Wetherick, N. E. (1976). The relation of reported imagery to cognitive perf mance. British Journal of Psychology, 67(4), 501-506. https://doi.org/10.1111/j.20448295.1976.tb01538.x

Einstein, A. (1952) Letter to Jacque Hadamard. In B. Ghiselin (Ed.), The creative process (pp. 4344). Berkeley, CA: University of California Press.

Ferrando, M., Soto, G., Prieto, L., Sáinz, M., \& Ferrándiz, C. (2016). Synthetic-creative intelligence and psychometric intelligence: Analysis of the threshold theory and creative process/sentetik-yaratici zeka ve psikometrik zeka: Esik kuramı ve yaratıcı süreç analizi. Türk Üstün Zekâ ve Egitim Dergisi, 6(2), 88-98.

Finke, R. A. (1996). Imagery, Creativity, and Emergent Structure. Consciousness and Cognition, 5(3), 381-393. https://doi.org/10.1006/ccog.1996.0024

Fuchs-Beauchamp, K. D., Karnes, M. B., \& Johnson, L. J. (1993). Creativity and intelligence in preschoolers. Gifted Child Quarterly, 37(3), 113-117.

https://doi.org/10.1177/001698629303700303

Gardner, H. (1983). Frames of Mind: The Theory of Multiple Intelligence. New York: Basic Books

Glăveanu, V. P., Karwowski, M., Jankowska, D. M., \& de Saint Laurent, C. (2017). Creative imagination. In T. Zittoun \& V. P. Glăveanu (Eds.), Handbook of imagination and culture (pp. 1-39). Oxford University Press.

Getzels, J. W., \& Jackson, P. W. (1960). Occupational choice and cognitive functioning: Career aspirations of highly intelligent and of highly creative adolescents. The Journal of Abnormal and Social Psychology, 61(1), 119-123. https://doi.org/10.1037/h0045583

Getzels, J. W., \& Jackson, P. W. (1962). Creativity and intelligence: Explorations with gifted students. New York: Wiley.

Gonzalez, M. A., Campos, A., \& Pérez, M. J. (1997). Mental imagery and creative thinking. The Journal of psychology, 131(4), 357-364. https://doi.org/10.1080/00223989709603521

Guilford, J. P. (1962). Potentiality for creativity. Gifted Child Quarterly, 6(3), 87-90. https://doi.org/10.1177/001698626200600307 
Guilford, J. P. (1967). Creativity: Yesterday, today and tomorrow. The Journal of Creative Behavior, 1(1), 3-14. https://doi.org/10.1002/j.2162-6057.1967.tb00002.x

Gündoğan, A. (2019). The Test of Creative Imagination: making the test suitable to the age group of 5-6 years. Early Child Development and Care, 189(8), 1219-1227.

https://doi.org/10.1080/03004430.2017.1372429

Hanggi, D. (1989). Differential aspects of visual short and long-term memory. European Journal of Cognitive Psychology, 1(4), 285-292. https://doi.org/10.1080/09541448908403089

Hoffmann, J., \& Russ, S. (2012). Pretend play, creativity, and emotion regulation in children. Psychology of Aesthetics, Creativity, and the Arts, 6(2), 175-184. https://doi.org/10.1037/a0026299

Holton, G. (1972). On trying to understand scientific genius. American Scholar, 41(1), 95-110. https://www.jstor.org/stable/41209034

Hu, W., \& Adey, P. (2002). A scientific creativity test for secondary school students. International Journal of Science Education, 24(4), 389-403. https://doi.org/10.1080/09500690110098912

Jauk, E., Benedek, M., Dunst, B., \& Neubauer, A. C. (2013). The relationship between intelligence and creativity: New support for the threshold hypothesis by means of empirical breakpoint detection. Intelligence, 41(4), 212-221. https://doi.org/10.1016/j.intell.2013.03.003

Karwowski, W., \& Gralewski, J. (2013). Threshold hypothesis: Fact or artifact? Thinking Skills and Creativity, 8, 25-33. https://doi.org/10.1016/j.tsc.2012.05.003

Kaufman, J. C., Kaufman, S. B., \& Lichtenberger, E. O. (2011). Finding creative potential on intelligence tests via divergent production. Canadian Journal of School Psychology, 26(2), 83106. https://doi.org/10.1177/0829573511406511

Kim, K. H. (2005). Can only intelligent people be creative? A meta-analysis. Journal of Secondary Gifted Education, 16(2-3), 57-66. https://doi.org/10.4219/jsge-2005-473

Kosslyn, S. M. (1980). Image and mind. London: Harvard University Press.

Lane, J. B. (1977). Problems in Assessment of Vividness and Control of Imagery. Perceptual and Motor Skills, 45(2), 363-368. https://doi.org/10.2466/pms.1977.45.2.363

Lindqvist, G. (2003). Vygotsky's theory of creativity. Creativity Research Journal, 15(2), 245-251. https://doi.org/10.1080/10400419.2003.9651416

Mourgues, C. V., Hein, T. M., Al-Harbi, S., Aljughaiman, A., \& Grigorenko, E. L. (2016). The relationship between analytical and creative cognitive skills from middle childhood to adolescence: Testing the threshold theory in the Kingdom of Saudi Arabia. Learning and Individual Differences, 52(2016), 137-147. https://doi.org/10.1016/j.lindif.2015.05.005

Muggeo, V. M. (2008). Segmented: an R package to fit regression models with broken-line relationships. $R$ news, 8(1), $20-25$.

Nusbaum, E. C., \& Silvia, P. J. (2011). Are intelligence and creativity really so different?: Fluid intelligence, executive processes, and strategy use in divergent thinking. Intelligence, 39(1), 36-45. https://doi.org/10.1016/j.intell.2010.11.002

Policastro, E., \& Gardner, H. (1999). From case studies to robust generalizations: An approach to the study of creativity. In R. J. Sternberg, \& R. J. Sternberg (Eds.), Handbook of creativity (pp. 213-225). New York: Cambridge University Press.

Preckel, F., Holling, H., \& Wiese, M. (2006). Relationship of intelligence and creativity in gifted and non-gifted students: An investigation of threshold theory. Personality and Individual Differences, 40(1), 159-170. https://doi.org/10.1016/j.paid.2005.06.022

Ripple, R. E., \& May , F. B. (1962). Caution in comparing creativity and IQ. Psychological Reports, 10(1), 229-230. https://doi.org/10.2466/pr0.1962.10.1.229 
Runco, M. A., \& Albert, R. S. (1986). The threshold theory regarding creativity and intelligence: An empirical test with gifted and nongifted children. Creative Child and Adult Quarterly, 11(4), 212-218.

Şahin, F. (2014). Yaratıcılık-zeka ilişkisi: Yeni deliller. İlköğretim Online, 13(4), 1516-1530.

Sak, U. (2004). About creativity, giftedness, and teaching the creatively gifted in the classroom. Roeper Review, 26(4), 216-222. https://doi.org/10.1080/02783190409554272

Sak, U. (2014a). Üstün zekâlılar: Özellikleri, tanılanmaları, eğitimleri. (4th ed.). Ankara: Vize Yayıncilik.

Sak, U. (2014b). Yaratıcılık gelişimi ve geliştirilmesi. Ankara: Vize Yayıncılık.

Shaw, G. A., \& Belmore, S. M. (1982). The Relationship between Imagery and Creativity. Imagination, Cognition and Personality, 2(2), 115-123. https://doi.org/10.2190/4RGA-Y1A6-HEK5LMF8

Shaw, G. A. (1985). The use of imagery by intelligent and by creative schoolchildren. The Journal of General Psychology, 112(2), 153-171. https://doi.org/10.1080/00221309.1985.9711000

Shaw, G. A., \& de Mers, S. T. (1987). Relationships between imagery and creativity in high-IQ children. Imagination, Cognition and Personality, 6(3), 247-262. https://oi.org/10.2190/R18BPUG2-4TBB-U4QP

Shi, B., Wang, L., Yang, J., Zhang, M., \& Xu, L. (2017). Relationship between divergent thinking and intelligence: an empirical study of the Threshold Hypothesis with Chinese children. Frontiers in Psychology, 8(254), 1-9. https://doi.org/10.3389/fpsyg.2017.00254

Singer, J. L. (1999). Imagination. In M. A. Runco, M. A. Pritzker, S. R. Pritzker, \& S. Pritzker (Eds.), Encyclopedia of creativity (pp. 13-25). California: Academic Press.

Sligh, A. C. (2003). The relation between intelligence and creativity in different intelligence levels. (Publication No. 3115075). [Doctoral dissertation, Alabama University]. https://search.proquest.com/docview/305334711?accountid=7181

Sligh, A. C., Conners, F. A., \& Roskos-Ewoldsen, B. (2005). Relation of creativity to fluid and crystallized intelligence. The Journal of Creative Behavior, 39(2), 123-136. https://doi.org/10.1002/j.2162-6057.2005.tb01254.x

Sternberg, R. J. (2004). Nonentrenchment in the assessment of intellectual giftedness. In J. S. Renzulli (Eds.), Identification of students for gifted and talented programs (pp. 43-52). California: Corwin Press.

Snyder, A., Mitchell, J., Bossomaier, T., \& Pallier, G. (2004). The creativity quotient: an objective scoring of ideational fluency. Creativity Research Journal, 16(4), 415-419. https://doi.org/10.1080/10400410409534552

Şahin, F., (2014). Yaratıcılık-zeka ilişkisi: Yeni deliller, Illköğretim Online, 13(4), 1516-1530.

Şahin, F. (2015). A Research on the structure of intelligence and creativity, and creativity style, Turkish Journal of Giftedness and Education, 5(1), 2-20

Tardif, T. Z., \& Sternberg, R. J. (1988). What do we know about creativity?. The nature of creativity. In R. J. Sternberg (Eds.), Contemporary psychological perspectives (pp. 429-438). New York: Cambridge University Press.

Thompson, W. L., Hsiao, Y., \& Kosslyn, S. M. (2011). Dissociation between visual attention and visual mental imagery. Journal of Cognitive Psychology, 23(2), 256-263.

https://doi.org/10.1080/20445911.2011.477810

Torrance, E. P. (1962). Guiding creative talent. Englewood Cliffs, NJ, US: Prentice-Hall, Inc.

Torrance, E. P. (1967). Understanding the fourth grade slump in creative thinking. Athens: University of Minnesota.

Vygotsky, L. S. (2004). Imagination and creativity in childhood. Journal of Russian \& East European Psychology, 42(1), 7-97. https://doi.org/10.1080/10610405.2004.11059210 
Yamamoto, K. (1964). Threshold of intelligence in academic achievement of highly creative students. The Journal of Experimental Education, 32(4), 401-405.

https://doi.org/10.1080/00220973.1964.11010849

Yılmaz, G. (2018). Eşik hipotezinin Asis Zekâ Ölçeği puanları ve yaratıcı hayal gücü kartları ile incelenmesi (Yayımlanmamış Yüksek Lisans Tezi). Anadolu Üniversitesi Eğitim Bilimleri Enstitüsü, Eskişehir, Türkiye.

Yilmaz, G. and Ayas, M. B. (2017, July 3-5). Examination of threshold theory with a new measure of Intelligence. Paper presented at 15th Internatinal Conference on Excellence in Education (ICIE), sözlü bildiri, Lisboa, Portugual.

\section{Ek A. Yaratıcı Hayal Gücü Kartlarında Kullanılan Şekiller}

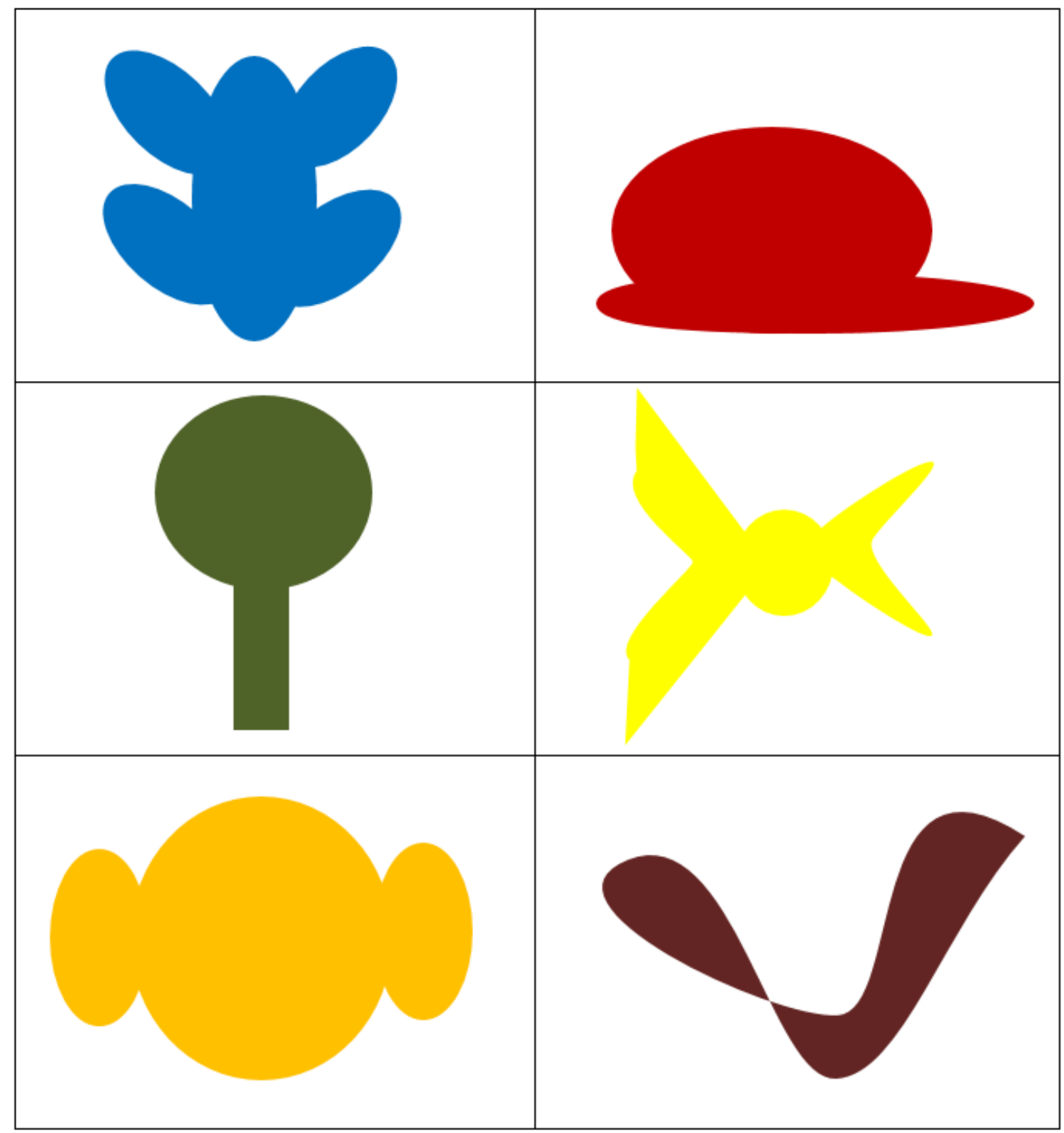

